\title{
INSTRUMENTY PROMOCJI POLSZCZYZNY W ŚWIECIE: „SPOTKANIA POLONISTYK TRZECH KRAJÓW - CHINY, KOREA, JAPONIA"
}

\section{POLITYKA JEZZYKOWA W ZAKRESIE PROMOCJI POLSZCZYZNY W ŚWIECIE}

Lektorzy języków obcych zdaja sobie sprawę, że przed podjęciem jakichkolwiek działań glottodydaktycznych osoba ucząca musi odpowiedzieć sobie na następujacce pytania: kto uczy?, kogo uczy?, z czego uczy?, gdzie uczy?, jak uczy? jak ocenia? itp. [Miodunka 2010, 41-54]. Zanim jednak możliwe będzie postawienie tych pytań przez osobę nauczająca języka polskiego jako obcego (JPJO), pojawić się powinni owi cudzoziemcy, zainteresowani językiem polskim i kultura polska - niezależnie od poziomu biegłości językowej. Słowem: by czegokolwiek kogokolwiek nauczyć, musimy mieć kogo uczyć. Jeśli na pierwszym planie umieści się kwestię pozyskiwania uczących się JPJO - przyszłych „ambasadorów" polskości, szczególnego znaczenia nabiora ustalenia specjalistów zajmujaccych się: kulturoznawstwem glottodydaktycznym, polityka językowa w zakresie promocji i nauczania JPJO w świecie, sytuacja polonistyki i nauczania JPJO w poszczególnych krajach i regionach swiata. Zapoznanie się $z$ tym wycinkiem badań uzmysławia, jak bardzo glottodydaktyka (osobna dziedzina nauki, majaca własne cele i metody badań), korzysta $z$ interdyscyplinarnego zaplecza, na które składaja się osiagnięcia nie tylko językoznawstwa i kulturoznawstwa, ale także socjologii, psychologii, politologii, studiów międzynarodowych, ekonomii, zarządzania i innych nauk. Wnioski płynące ze wszystkich tych obszarów wiedzy, integrowane i przeformułowywane w kategoriach glottodydaktycznych, stanowić powinny arsenał środków wykorzystywanych przez odpowiedzialnych nauczycieli JPJO budujących wizerunek państwa. To właśnie on wpływa na to, jak społeczności, te narodowe i ponadnarodowe, postrzegaja polskość. Pozycja i prestiż naszego kraju, a także liczba i ranga jego sojuszników, zależą także od oddolnych działań lektorów JPJO, a także przedstawicieli polonistyk międzynarodowych (międzykulturowych) - wywodzących się z innych języków i kultur. 
Kontekst polonistyczny i glottopolonistyczny pozwala umieścić wśród odbiorców działań polskiej dyplomacji publicznej (DP) wszystkie osoby uczące się JPJO na świecie, ze szczególnym uwzględnieniem młodych dorosłych i dorosłych, bardzo często zawdzięczających swoją znajomość polszczyzny i wiedzę na temat Polski środowisku akademickiemu (lub $z$ nim związanych). Zagraniczni studenci i wykładowcy stanowić będa $\mathrm{w}$ tym zbiorze grupę najważniejsza, $z$ trzech powodów.

Po pierwsze - pojawienie się studiów polskich na poziomie uniwersyteckim w systemie szkolnictwa danego kraju jest sprawa prestiżową. Oznacza, iż sprawy polskie funkcjonuja w lokalnej tradycji społeczno-humanistycznej na poziomie i badawczym, i zawodowym. Instytucje państwowe i podmioty pozarządowe zyskuja ekspercki poziom odniesienia, jeśli tylko pojawia się potrzeba zgłębienia jakichkolwiek kwestii szczegółowych.

Po drugie - to właśnie środowisko akademickie odpowiada za wykształcenie ośrodków zajmujących się polszczyzna (jej badaniami, ochrona, popularyzacja), a także stworzenie i rozwinięcie glottodydaktyki polonistycznej (GP). To ono także, dzięki zaangażowaniu zagranicznych slawistyk i polonistyk, niezależnie od zmian politycznych, odpowiada za upowszechnianie polszczyzny w świecie. Zagraniczne (akademickie) ośrodki polonistyczne są zazwyczaj głównym miejscem umożliwiającym studentom obcokrajowcom kontakt $z$ polska kultura. Ten stan rzeczy znajduje potwierdzenie $\mathrm{w}$ istniejacym podziale DP na obszary: $\mathrm{w}$ oczach urzędników państwowych popularyzacja polszczyzny w świecie połączona jest $z$ dyplomacja naukową.

Trzeci powód najlepiej oddaje tytuł jednego z podrozdziałów (5.6) $D y$ daktyki i metodyki nauczania języka polskiego jako obcego i drugiego W.T. Miodunki i P. Gębala: „Władze państwowe czy instytucje akademickie - kto prowadzi w Polsce polityke językową?" [Gębal, Miodunka 2020, 136]. Autorzy omawiaja dokonania wybitnych specjalistów reprezentujących polskie środowisko językoznawcze, którzy odpowiedzieli na wyzwania swoich czasów i przedstawili koncepcje programowe polskiej polityki językowej dotyczace promocji polszczyzny i wśród obywateli polskich, i w rozsianych po całym świecie skupiskach polonijnych, a także wśród obcokrajowców niepolskiego pochodzenia (szczególnie - przedstawicieli państw członkowskich Unii Europejskiej). ${ }^{1}$ Jednakże rozczarowani stwierdzaja, że

1 Krótką listę prac omówionych przez W.T. Miodunkę i P. Gębala poszerzam oraz podaję w porządku chronologicznym: Miodunka 1990, Dubisz 1997, Mazur 1998 i 1999, Lubaś 1999, Pisarek 1999, Gajda 1999 i 1999a, Dubisz 2001, Gajda, Markowski, Porayski-Pomsta 2005, Dubisz 2007, Mazur, Rzeszutko-Iwan 2007, Warchala, Krzyżyk 2008, Pawłowski 2008, Lubaś 2009, Szul 2009 , Garbacik-Jeziorska 2011, Dąbrowska, Miodunka, Pawłowski 2012, Lubaś 2012, Dubisz 2013 i 2015, Pawłowski 2015, Miodunka, Tambor i in. 2018. 
patrząc na dorobek polskiej polityki językowej z perspektywy ostatnich 20 lat, możemy pokusić się o dokonanie oceny jej rezultatów w praktyce, które nie odpowiadaja wielkościom zakładanym w programach, co łatwo stwierdzić, porównując poszczególne ich zadania $z$ rezultatami osiagniętymi w rzeczywistości. Stało się tak, ponieważ wysiłek intelektualny najwybitniejszych językoznawców polskich nie znalazł należytego zrozumienia i oddźwięku wśród przedstawicieli tzw. polskiej klasy politycznej, pozbawionej świadomości znaczenia okresu, w którym przyszło jej działać oraz szans stojących przed kultura polska, z językiem polskim na czele [Gębal, Miodunka 2020, 136].

Stanisław Dubisz zgadza się z autorami Dydaktyki i metodyki..., stwierdzając że „de facto polska polityka językowa pozostaje dziś w sferze faktów niedokonanych" [Dubisz 2020, 120].

Zdaniem W.T. Miodunki i P. Gębala [2020, 138] sytuacja mogłaby być inna, gdyby na szczeblu najwyższym uniknięto tworzenia wielu instytucji „uwikłanych” w promocję języka, ich rozdrobnienia, odpowiednio skoordynowano ich działania, powołano jedna instytucję zarządzająca promocją i nauczaniem polszczyzny w świecie. ${ }^{2}$ Może wtedy udałoby się zapewnić właściwa, jak pisze S. Dubisz, „promocję kultury narodowej $\mathrm{w}$ tym języka polskiego - poza granicami państwa polskiego tak $\mathrm{w}$ środowiskach polonocentrycznych, jak i innoetnicznych" [Dubisz 2020, 120]. ${ }^{3}$

Tak się jednak nie stało - co, paradoksalnie, pozytywnie wpłynęło i wpływa zarówno na środowisko glottopolonistyczne, jak i międzynarodowe środowisko polonistyczne (w tym, rzecz jasna, na zagranicznych studentów i wykładowców - którzy na początku swej drogi sami byli studentami, czyli „naturalne lobby sprzyjajacce rozwojowi wzajemnych stosunków" [Chomicki 2009, 52]) - realizujące oddolne, międzynarodowe działania polonistyczne i glottopolonistyczne, „robiące swoje” niejako w odpowiedzi na słowa wyartykułowane przed laty przez Annę Dąbrowską [2008, 136-137]. To za przykładem wrocławskiej badaczki oraz naukowców $z$ innych najważniejszych ośrodków glottopolonistycznych podażamy od wielu lat, w Polsce i poza jej granicami, i po prostu „robimy swoje”!

2 Powołanie Narodowej Agencji Wymiany Akademickiej to krok w dobra stronę, jednakże instytucja ta funkcjonuje (w dalszym ciagu) w rzeczywistości "rozdrobnienia”.

3 Pozostałe główne zadania, które powinna zapewnić polityka językowa państwa polskiego, wymienione przez S. Dubisza, to: właściwa ranga i jakość dydaktyki języka polskiego na każdym szczeblu szkolnictwa, w kraju i w zbiorowościach polonocentrycznych poza jego granicami; właściwa pozycja polszczyzny w sferze administracyjno-prawnej i medialnej (w tym certyfikacja znajomości JPJO oraz wymiana oficjalnych dokumentów w obiegu międzynarodowym). 


\section{NARZĘDZIA DYPLOMACJI PUBLICZNEJ: POLONISTYKI ZAGRANICZNE}

Jeśli jednym $z$ priorytetowych celów polskiej polityki językowej (mimo oddolnego sposobu realizacji) jest promocja języka polskiego poza granicami kraju, to prozaiczne kwestie zwiazane $z$ codzienna praca lektoratowa w zakresie nauczania JPJO i kultury polskiej jako obcej (KPJO), w kraju i poza jego granicami, wpisują się w działania DP o „parasolowym” charakterze [Skoczek 2021]. Gdy więc przyjmuje się, że do prowadzenia działań we wszystkich obszarach DP wykorzystywane sa jej narzędzia: badania wizerunkowe i monitoring mediów publicznych, współpraca $z$ mediami, Internet i media społecznościowe, wizyty studyjne, debaty i edukacja, wystawy, publikacje, twinning (projekty bliźniacze), umowy międzyrządowe, konkursy dotacyjne dla organizacji pozarządowych - należy przedstawić postulat poszerzenia tego katalogu przynajmniej o trzy istotne składowe. Sa nimi: zagraniczne lektoraty (lekcje, ćwiczenia, konwersatoria itp.) JPJO, lektorzy JPJO oraz poloniści zagraniczni.

Działalność lektorów JPJO jest w tym układzie fundamentalna, albowiem bez nich nie istniałaby polonistyka zagraniczna i nie byłoby cudzoziemskich specjalistów - których przecież ktoś (nauczyciele JPJO) kiedyś nauczył polszczyzny [Miodunka 2020, 17]. Zatem to dzięki lektorom nastapiło „otwarcie się" języka polskiego na świat - doprowadzili oni bowiem do sytuacji, w której polonistyka zyskuje wymiar międzykulturowy.

Określenia polonistyka zagraniczna używam świadomie, wbrew postulatowi Tokimasy Sekiguchiego z 2012 r. W swoim pamiętnym wystąpieniu na Kongresie Polonistyki Zagranicznej w Opolu krytykował on nazwę kongres polonistyki zagranicznej jako zdradzająca

pokutowanie ograniczonej, anachronicznej, polonocentrycznej percepcji nauki, bazującej na przeświadczeniu, że jedynie w Polsce możliwe sa prawdziwe badania naukowe i prace dydaktyczne, których przedmiotem jest język polski i jego pochodne zjawiska kulturowe.

Japoński badacz pisał dalej, że

kategoryzacja przeciwstawiająca „zagraniczne” wobec „krajowego” zakłada nieciągłość naszej działalności akademickiej zależnej od granic: geograficznej i państwowej, marginalizując jednocześnie to pierwsze wobec drugiego według schematu: peryferie i centrum, prowincje i stolica, obczyzna i ojczyzna [Sekiguchi 2014, 774-775].

Argumentów jednego $z$ najwybitniejszych w historii polonistów nie można pominąć, jednakże należy przyznać, że po długim okresie mozolnych działań specjalistów nieurodzonych w Polsce zanika ów „introwersyjny reżim dotychczasowej filologii polskiej” oraz przekonanie, że język polski jest własnością rodowitych Polaków i Polonii. Fakt, że „istnieją ludzie nie-Polacy, którzy chcą czytać i wyrażać siebie tym językiem” [Se- 
kiguchi 2013, 100], jest bezsporny. Ludziom tym zawdzięczamy usamodzielnienie się nauki i specjalizacji nauczania JPJO oraz światowe rozszerzanie geografii polskiej glottodydaktyki. To celne określenie wypowiedziane przez T. Sekiguchiego nabiera specjalnego znaczenia, gdy weźmiemy pod uwagę fakt, iż odnosi się do rozwoju polonistyki w regionie czysto „niepolonijnym”, mianowicie w Japonii, Republice Korei i Chinach [Sekiguchi 2013, 100].

Biorąc pod uwagę powyższe, stwierdzam, iż dla mojej (i młodszych) generacji glottodydaktyków polonistycznych jasne jest, cytując W.T. Miodunkę [2000, 30], że „nie można przenosić wyobrażeń i wiedzy o polonistyce krajowej na polonistykę zagraniczna”. Tej drugiej zawdzięczamy grono przyjaciół, miłośników, sympatyków, fanów, budujących wizerunek i pozycję kultury polskiej w rozmaitych miejscach na świecie - oraz wiążący się z tym prestiż. Kontekstowość uprawiania glottodydaktyki, konieczność adaptowania się do rozlicznych zmiennych towarzyszących procesowi glottodydaktycznemu, uczy pokory oraz buduje szacunek dla zagranicznych kolegów - którzy nie z przymusu, lecz z serca towarzyszą polskości, mając pełne prawo wypowiadania się w sprawach polskich. Osoby, o których mowa, stanowia przecież elitę intelektualna - nie tylko w kraju swojego pochodzenia. Gdy zabraknie ich siły i entuzjazmu, zainteresowanie naszym językiem i kultura, wywołane jakimiś ważnymi wydarzeniami, będzie miało charakter okresowy. ${ }^{4}$

Do grona polonistów zagranicznych zalicza się wszystkich specjalistów zajmujących się polskimi, polonoznawczymi i polonistycznymi tematami na najwyższym poziomie szkolnictwa poza granicami kraju, ${ }^{5}$ niezależnie od uprawianych przez nich dyscyplin. W naturalny sposób do tego kręgu wchodzą kulturoznawcy, literaturoznawcy, językoznawcy,

4 Od lat zwracał na to uwage Jan Mazur, uzależniając szybka regenerację i dalszy rozwój polonistyk w świecie od wsparcia instytucji państwa polskiego [Mazur 2000].

5 Świadomie unikam kreślenia różnic między polonistykami „prawdziwymi”, filologicznymi, studiami polskimi, polonoznawstwem, „tylko” lektoratem języka polskiego (tj. kursem języka obcego), usytuowanym organizacyjnie w ramach lokalnej szkoły języków obcych lub szkoły języków rzadziej nauczanych itd. [por. np. Dąbrowska, Miodunka, Pawłowski 2012]. Zastanawiając się nad różnymi kwestiami związanymi $z$ upowszechnianiem JPJO, wszystkie inicjatywy i formy organizacyjne pojawiajace się na szczeblu akademickim uznaję za tak samo ważne i potrzebne. Oczywiście, w dalszych rozważaniach należałoby przyjrzeć się także: rozmaitym modelom tak zwanych polonistyk (m.in. lektor z Polski i lokalny profesor zajmujący się Polską), różnicom w funkcjonowaniu placówek obsadzanych lektorami Narodowej Agencji Wymiany Akademickiej [por. https:// nawa.gov.pl/jezyk-polski/program-lektorzy] i takich, które w inny sposób dokonują wyboru specjalistów zajmujących się nauczaniem JPJO (por. np. Niemcy, USA, Kanada, Ukraina), problemom wynikającym $z$ braku precyzyjnego określenia statusu lektora zagranicznego (co jest także wynikiem „niezauważania” przez stosowne resorty istnienia zawodu lektora JPJO) itd. 
ale także historycy, politolodzy i inni - czasem nawet przedstawiciele nauk tak odległych jak ścisłe czy przyrodnicze. Przykładem tego typu sytuacji sa np. trudne losy północnych Koreańczyków i Wietnamczyków, którym w drugiej połowie XX wieku ich władze narzucały kierunki studiów, niezależnie od faktycznych osobistych zainteresowań [Wrocławski 2006, 77]. Interdyscyplinarne potrzeby polonistyki i glottodydaktyki polonistycznej widać zwłaszcza po 1989 i 2004 r., kiedy „powrót Polski do świata i Europy spowodował, że polszczyzna przestała być językiem studiowanym tylko przez językoznawców, literaturoznawców, historyków i pianistów" [Sekiguchi 2013, 99].

Na znaczenie tych specjalistów w środowisku wpływ ma nie tylko pozycja w świecie nauki, ale - przede wszystkim - działalność dydaktyczna i organizatorska, pozwalająca skutecznie funkcjonować jednostce uczelnianej oraz przyciagać studentów, poszukujących nie tylko atrakcyjnej ścieżki kariery, ale także charyzmatycznych wykładowców, ludzi o talentach pedagogicznych, wiarygodnych przewodników interkulturowych i tzw. dobrych gospodarzy. Wszystkie te elementy składaja się na dobrego polonistę zagranicznego (a także - na lektora JPJO), odpowiedzialnego za zwiększanie prestiżu JPJO w danej części świata, rozwijającego polonofonię [Miodunka 2011], promującego wszelkie polskie dokonania, kształcącego przyszłych „ambasadorów” polskości i specjalistów odnoszących sukcesy zawodowe na styku dwu lub więcej kultur.

\section{MIGRACJA GLOBALNEJ METROPOLII}

Współcześnie zachodzące procesy polityczno-ekonomiczne jednoznacznie potwierdzaja, iż $z$ roku na rok rośnie gospodarcze znaczenie regionu Azji i Pacyfiku (a zwłaszcza Chin, które stały się nowym globalnym graczem, realizującym szereg ambitnych i dalekosiężnych planów). Potwierdzaja to m.in. badania Danny'ego Quaha [2011], który zauważył przed laty, że środek ciężkości światowego PKB przesuwa się w stronę południowo-wschodnia globu (mimo faktu, iż finansowe wpływy USA wciąż pozostaja ogromne; co jest zrozumiałe, bo centrum finansowe świata siła rzeczy przesuwa się wolniej niż gospodarcze). Sytuacja ta nie uszła uwadze planistów kształtujących polską politykę zagraniczna, którzy dopiero po przystapieniu Rzeczpospolitej do Unii Europejskiej spróbowali uzgodnić polska rację stanu ze zmodyfikowana sytuacja międzynarodowa.. ${ }^{6}$ Odziedziczona po okresie PRL-u pewna dobra tradycja współpracy

${ }^{6}$ K. Szumski [2013, 28] pisze, że zmiana podejścia polskiej polityki zagranicznej do stosunków z krajami Azji i Pacyfiku zaczęła następować w latach 2008-2010. Ówczesny minister spraw zagranicznych, Radosław Sikorski, polskie relacje $z$ krajami Azji i Pacyfiku uznawał przede wszystkim za „nasz wkład w realizację polityki unijnej w kontekście powstającego nowego układu 
gospodarczej i edukacyjnej Chin, Indii, Wietnamu czy Indonezji z Polską pozostawiła, jak wspomina Krzysztof Szumski [2013, 11-12], przekonanie o solidności i dobrym poziomie polskich partnerów oraz celowości współpracy gospodarczej z Polską w nowej rzeczywistości.

Nie wydaje się, by kolejne rzady RP odpowiednio skorzystały ze zgromadzonego przed 1989 r. kapitału. Było to zrozumiałe w latach 90. XX w., kiedy to priorytetem dla naszego kraju była, o czym przypomina Tadeusz Chomicki, odbudowa struktur demokratycznych państwa i gospodarki, stworzenie podstaw społeczeństwa obywatelskiego i przywrócenie Polsce należnego jej miejsca w Europie oraz dołączenie do NATO i UE:

nic więc dziwnego, że wysiłki i środki w polityce zagranicznej skupiły się niemal całkowicie na kierunku europejskim i transatlantyckim kosztem zaniechania aktywnych działań na innych obszarach [Chomicki 2009, 40-41].

Ograniczone zasoby finansowe, ludzkie i organizacyjne nie pozwoliły na wzrost pozycji naszego kraju w tym makroregionie.

Przykłady zaczerpnięte $z$ działań środowiska akademickiego pokazują, że po raz kolejny można było liczyć na „robiących swoje” oddolnie, czyli przedstawicieli świata akademickiego, wykładowców i studentów. $\mathrm{W}$ dużym stopniu to dzięki nim nie zerwano więzi ze wschodnio- i południowoazjatyckimi partnerami, a nawet ustanowiono nowe połaczenia, oparte na zapleczu naukowym i akademickim, pozwalajace na wychowanie kadr mogących przyczynić się do pogłębiania współpracy w rozmaitych dziedzinach życia.

$Z$ czasem zmieniła się międzynarodowa pozycja RP - nasza obecność we Wspólnocie Europejskiej oraz aspiracje dotyczące większego zaangażowania Polski w sprawy UE zaowocowały zwiększonym zainteresowaniem państw azjatyckich, dotyczącym także sfery kultury i kontaktów międzyludzkich. ${ }^{7}$ Przełożyło się to na nowe działania i inicjatywy, podejmowane w kolejnych latach - także na te istotne $z$ perspektywy glottopolonistycznej: m.in. na promocję Polski w makroregionie oraz odpowiedni klimat polityczny ${ }^{8}$ do tworzenia nowych projektów polonistycznych na

sił w świecie”. Pomysł nowelizacji strategii państwa polskiego możliwy był także dzięki wcześniejszym badawczym dokonaniom ekspertów uprawiających studia międzynarodowe (m.in. Edward Haliżak, Jakub Zajączkowski - reprezentujący Uniwersytet Warszawski).

7 K. Szumski [2013, 25] podaje pierwszy zwiastun nadchodzacych zmian w postrzeganiu RP, mianowicie wizytę w Warszawie prezydenta Chin, Hu Jintao, w czerwcu 2004 r. Przyjęte wówczas ustalenia wytyczyły kierunki stosunków obu państw na następnych siedem lat, przygotowując grunt pod kolejne ocieplenie relacji [por. Burdelski 2010].

8 Truizmem jest stwierdzenie, że ów klimat polityczny jest zmienny. Na same stosunki polsko-chińskie wpływ miały rozliczne spotkania, incydenty i wydarzenia pojawiające się na scenie krajowej i/lub europejskiej przed „ociepleniem” spowodowanym polskim udziałem w Wystawie Światowej EXPO 2010 w Szan- 
poziomie akademickim (np. w Chinach). Zyskała na nich marka Polski, wcześniej bardzo słabo rozpoznawalna w Azji Wschodniej. Duża w tym zasługa projektów realizowanych w Azji Wschodniej (i Indiach) już od 2005 r. przez Instytut Adama Mickiewicza [Jacoby 2013; Jurkiewicz-Eckert 2016], majacych na celu budowanie obecności Polski w tym regionie przez kulturę. Konkretne działania w ramach hybrydowego projektu brandingowego „Program Azja”, zrealizowane w Chinach i Hongkongu, Indiach, Japonii, Korei Południowej i Wietnamie, we współpracy m.in. z polskimi placówkami dyplomatycznymi, Instytutami Polskimi i in., dostosowane do lokalnych uwarunkowań i możliwości działania, przysporzyły Rzeczpospolitej licznych (toutes proportions gardées) zwolenników.

Wzrosła liczba osób, które nie traktuja Rzeczpospolitej Polskiej jako kraju zwiazanego tylko z Chopinem, Kopernikiem i Skłodowska-Curie. Zanotowaliśmy także wzrost liczby studentów decydujących się na wybór studiów związanych $z$ Polska, jej językiem i kultura, przekonanych o możliwości znalezienia dobrej pracy po uzyskaniu dyplomu. Nie ma całościowych danych pozwalających sprawdzić, jak duża jest ta grupa. Natomiast istnieją statystyki dotyczące studentów zagranicznych kształconych w Polsce. Poniższa tabela pokazuje, ilu obywateli ${ }^{9}$ państw Azji Wschodniej i Południowej uczęszczało na zajęcia oferowane przez krajowe szkoły wyższe w latach 2016-2019 (opracowanie własne). ${ }^{10}$

ghaju oraz wizyta prezydenta Bronisława Komorowskiego w Chinach w 2011 r. - wtedy to range relacji dwustronnych podniesiono do poziomu partnerskich stosunków strategicznych [Szumski 2013, 31; Y. Zhang 2021]. Interwencjonizm państwowy tradycyjnie funkcjonujący w krajach Azji Wschodniej powoduje, że polskie działania biznesowe w makroregionie, by być skuteczne, potrzebuja wsparcia politycznego przedstawicieli władz RP.

9 Osobnego omówienia wymagałyby grupy emigrujace do Polski. Temu tematowi poświęcono wiele prac, m.in. Wysieńska 2012 oraz Wardęga 2017. W tym ostatnim tekście Joanna Wardęga zauważa, że dzięki koncepcji Nowego Jedwabnego Szlaku Europa Środkowo-Wschodnia, która nie była tradycyjnym celem chińskiej emigracji, wyraźniej niż kiedykolwiek wcześniej zaistniała w świadomości Chińczyków. Ostatnie dwie dekady to dynamiczny wzrost liczebności chińskiej mniejszości w Polsce.

10 Dane za lata 2016 i 2016/17 - pochodza $z$ raportów programu „Study in Poland”, publikowanych przez Fundację Edukacyjna Perspektywy: raport Studenci zagraniczni $w$ Polsce 2016, https:/ / perspektywy.pl/portal/index.php?option=com_content\&view=article\&id=2899:w-polsce-studiuje-57-119-studentowzagranicznych-ze-157-krajow\&catid=22\&Itemid=119 [dostęp: 11.01.2021] oraz Studenci zagraniczni $w$ Polsce 2017, za rok akademicki 2016/17, http://studyinpoland.pl/konsorcjum/index.php?option=com_content\&view=article\&id=14515:raport-studenci-zagraniczi-w-polsce-2017\&catid=258:145-newsletter-2 017\&Itemid=100284 [dostęp: 11.01.2021].

Dane za 2019 r. - pochodza z raportu Głównego Urzędu Statystycznego $z$ dn. 30.10.2020 r. pt. Szkolnictwo wyższe i jego finanse w 2019 roku, https:/ / stat.gov.pl/obszary-tematyczne/edukacja/edukacja/szkolnictwo-wyzsze-i-jegofinanse-w-2019-roku,2,16.html [dostęp: 11.01.2021]. 


\begin{tabular}{|c|c|c|c|}
\hline & 2016 & $2016 / 17$ & 2019 \\
\hline \multicolumn{4}{|l|}{ Azja Wschodnia } \\
\hline Azja Pólnocno-Wschodnia & 1668 & 2056 & 2892 \\
\hline Chiny & $850^{*}$ & $961^{* *}$ & $1510^{* * *}$ \\
\hline Tajwan & 505 & 758 & 1007 \\
\hline Japonia & 67 & 74 & 128 \\
\hline Korea Południowa & 100 & 117 & 117 \\
\hline Korea Północna & 7 & 5 & 14 \\
\hline Mongolia & 139 & 141 & 116 \\
\hline Azja Poludniowo-Wschodnia & 548 & 697 & 1200 \\
\hline Filipiny & 8 & 15 & 40 \\
\hline Malezja & 182 & 185 & 136 \\
\hline Indonezja & 19 & 59 & 180 \\
\hline Singapur & 5 & 7 & 12 \\
\hline Tajlandia & 95 & 157 & 299 \\
\hline Brunei & - & - & - \\
\hline Kambodża & - & 1 & 2 \\
\hline Laos & 1 & 11 & 8 \\
\hline Mjanma & 4 & 6 & 23 \\
\hline Wietnam & 234 & 256 & 500 \\
\hline \multicolumn{4}{|l|}{ Azja Południowa } \\
\hline & 1249 & 2815 & 4155 \\
\hline Indie & 896 & 2138 & 3388 \\
\hline Pakistan & 128 & 151 & 222 \\
\hline Nepal & 134 & 337 & 196 \\
\hline Bhutan & 1 & - & - \\
\hline Bangladesz & 66 & 160 & 252 \\
\hline Sri Lanka & 24 & 29 & 97 \\
\hline Malediwy & - & - & - \\
\hline
\end{tabular}

* W tym: Hongkong -6 .

** W tym: Hongkong - 8 .

*** W tym: Hongkong - 16, Makau - 2 . 
Dopiero w ostatniej dekadzie Rzeczpospolita przyspieszyła budowanie nowych podstaw swej obecności w tej części świata. Czy okażą się one trwałe? Szkicując w 2009 r. perspektywy polskiej obecności w regionie Azji i Pacyfiku, T. Chomicki twierdził, iż „większość „azjatyckiego tortu" została już podzielona, ale po smakowite resztki można jeszcze sięgnaćc" [Chomicki 2009, 49]. Miejmy nadzieję, że chwilowe spowolnienie pozwoli Polsce utrzymać wpływy na tym obszarze - odpowiadające międzynarodowej, niemocarstwowej przecież pozycji RP. Nie można zapominać o przestrodze sformułowanej przed laty przez T. Chomickiego, wytrawnego dyplomatę i znawcę tematu:

Nieobecność Polski w tym regionie lub jej słaba tam pozycja, będąca wynikiem braku reakcji na globalny trend, skazać moga nasz kraj na marginalizację lub ograniczenie jego roli jedynie do funkcji państwa lokalnego, działającego w ramach UE i najbliższej zagranicy. W dłuższej perspektywie prowadziłoby to także do stopniowego osłabienia polskiej pozycji w Unii. Pytaniem nie jest więc dzisiaj, czy Polska musi zwiększyć swe zaangażowanie w rejonie Azji i Pacyfiku, ale jak powinna to robić [Chomicki 2009, 49]. ${ }^{11}$

\section{INTEGRACJA POLONISTÓW Z AZJI WSCHODNIEJ}

Polonistyki w Azji Wschodniej i Południowej powstawały w różnych okresach. Pekińska ${ }^{12}$ - w 1954 r., ze względu na potrzeby i (internacjonalistyczna) politykę bloku państw socjalistycznych. Relacje nawiazane prawie 70 lat temu przetrwały rozmaite zawirowania polityczne, ideologiczne, a także dynamiczne zmiany społeczno-ekonomiczne zachodzace w obu państwach. Zwłaszcza środowisko naukowe prawidłowo oceniło stale rosnacca rolę Chin w regionie i na świecie. Prawie od zera rozwijała się współpraca kulturalna, naukowa i edukacyjna z Republiką Korei. Polonistyka seulska rozpoczęła swoją działalność w 1987 r., jeszcze zanim nawiazane zostały kontakty dyplomatyczne między Polska a Koreą Południowa. Jej powstanie to efekt wyobraźni i determinacji Byunga Kwona Cheonga, przewidującego korzyści, które może przynieść obu państwom przyszła współpraca gospodarcza, zwiąana $z$ sukcesem gospodarki koreańskiej. Polonistykę tokijska powołano dopiero w 1991 r., w reakcji władz japońskich na zmianę sytuacji w Europie Środkowej, ale spożytkowując wcześniejsze dekady prac zasłużonych specjalistów z Kraju Kwitnącej Wiśni [Sekiguchi 2013, Miodunka 2018]. Przed 1966 r. nie było w Japonii lektoratów JPJO organizowanych na poziomie uniwersyteckim. Dopiero w tym właśnie roku wprowadzono na Tokyo University of Foreign Studies przedmioty „język polski” i „studium porównawcze języków słowiańskich". W 1968 r. otwarto także lektoraty na Uniwersytecie

11 Por. Walczak, Mielczarek 2013.

12 Li Yinan [2018, 328] pisze, że w ciagu niecałych 70 lat wykształciła ok. 200 polonistów. 
Waseda i uczelni Kyoto Sangyo [Sekiguchi 1997, 209]. W ostatnich kilkunastu latach zmalało jednak zainteresowanie Japończyków Polska, która przestała być „socjalistyczna atrakcja”, a stała się „jednym $z$ wielu krajów Europy" [Sekiguchi 2013, 16-17].

Pozostałe „tradycyjne” miejsca, tj. te, w których lektoraty języka polskiego powstały kilkadziesiąt lat temu, ze względu na politykę PRL (i ZSRR), to Indie i Wietnam. Nauczanie JPJO na Uniwersytecie Delhijskim istnieje od 1968 r. (stosunki dyplomatyczne nawiazano w 1954 r.). Lektorat JPJO w Wyższej Szkole Języków Obcych w Hanoi (dzisiejszy HANU - Uniwersytet Hanojski) - rozpoczał działalność w 1973 r., mimo że stosunki dyplomatyczne między Polska a Wietnamem nawiązano w 1950 r., a WSJO powstała w 1959 r. Na losy uczelni wpływ miała wojna ze Stanami Zjednoczonymi.

Sytuacja wymienionych ośrodków jest wyjątkowo ciekawa dla glottodydaktyków polonistycznych, gdyż funkcjonują one w rzeczywistości najczęściej albo pozbawionej wsparcia Polonii i organizacji polonijnych, albo przy nieznacznym jej udziale. ${ }^{13}$ Niewielu jest Polaków na stałe przebywajacych w krajach Azji Wschodniej i Południowej, w zwiazku z czym - najczęściej - jedyną wyspe polskości stanowią uczelniane katedry polonistyczne, polskie placówki dyplomatyczne, czasem przedstawicielstwa polskich firm działających w tym regionie, a także służbowe mieszkania polskich nauczycieli JPJO. ${ }^{14}$ Lektorzy nauczaja języka polskiego jako „prawdziwie” obcego, kultura polska jest rzeczywiście odległa i obca, dlatego też tak istotne sa dla uczących się wyjazdy stypendialne, umożliwiające bliższy kontakt $z$ przedmiotem nauki. Przepływy studentów i wykładowców, coraz intensywniejsze kontakty uczestników procesu glottodydaktycznego, przynoszą owoce: coraz więcej publikuje się prac

13 Elżbieta Sękowska [2010, 20-24], analizując polszczyznę emigracji polskiej w świecie, podała orientacyjne liczby dotyczące obecności Polaków (Polonii) w różnych państwach świata. W następujących krajach Azji Wschodniej i Południowej było to (ok.) tyle osób: Chiny - 300, Singapur - 200, Filipiny - 100, Indie - 100, Indonezja - 100, Korea Południowa - 100, Malezja - 100, Tajlandia - 100, Tajwan - 100, Wietnam - 100, Pakistan - 50, Bangladesz - 20, Korea Północna - 11 .

$14 \mathrm{Z}$ informacji zawartej w Bazie organizacji oraz instytucji polskich $i$ polonijnych za granica Głównego Urzędu Statystycznego, opublikowanej w styczniu 2019 r. [https://stat.gov.pl/obszary-tematyczne/ludnosc/polonia-i-polacy-w-swiecie/baza-organizacji-i-instytucji-polskich-i-polonijnych-za-granica, 2,3. html - dostęp: 14.01.2021], wynika, że w interesującym mnie regionie istnieja następujące podmioty: Zagraniczne Biura Handlowe Polskiej Agencji Inwestycji i Handlu (w: Chengdu, Szanghaju, Mumbaju, Dżakarcie, Tokio, Seulu, Kuala Lumpur, Ułan Bator, Singapurze, Tajpej, Ho Chi Minh), zagraniczne przedstawicielstwa handlowe (m.in. Biuro KGHM Polska Miedź S.A. w Szanghaju), instytucje gospodarcze i oświatowe, organizacje i instytucje wyznaniowe, cmentarze i miejsca pochówku, serwisy internetowe, fundacje i stowarzyszenia. 
poświęconych problemom i wyzwaniom towarzyszącym kształceniu poszczególnych grup narodowych i etnicznych.

W 2007 r., z okazji 20-lecia polonistyki na Koreańskim Uniwersytecie Języków Obcych (HUFS - Hankuk University of Foreign Studies) w Seulu (Yonginie), zorganizowana została konferencja międzynarodowa „Studia Polskie w Azji”. Po raz pierwszy doszło do spotkania polonistów i polonoznawców z Korei Południowej, Chin i Japonii. ${ }^{15}$ Tak oto powołano do życia jedna $z$ najważniejszych inicjatyw pozarzadowych zbudowanych wokół nauczania języka polskiego i kultury polskiej w świecie: „Spotkania polonistyk trzech krajów - Chiny, Korea, Japonia” (SPTK). Wywodzący się $z$ Azji Północno-Wschodniej (a dokładniej - z ośrodków: pekińskiego, seulskiego i tokijskiego) badacze, dydaktycy i organizatorzy utworzyli swoisty mechanizm współpracy polonistów swojego regionu, zapewniający ich głosom słyszalność. Tak oto aktywność lokalna, dzięki konsekwentnym, cyklicznym działaniom inicjatorów, doprowadziła do tego, że inicjatywę tę zauważyli poloniści z innych krajów [Miodunka 2018, 33].

W latach 2009-2020 zorganizowano sześć SPTK (siódma konferencja, zaplanowana w 2020 r. w Pekinie (BFSU), nie odbyła się ze względu na sytuacje pandemiczna). Organizatorem pierwszego spotkania w 2009 r. w Tokio był Tokijski Uniwersytet Studiów Międzynarodowych (Tokyo University of Foreign Studies; TUFS/TUJO). Kolejne spotkanie zorganizował w stolicy Chin Pekiński Uniwersytet Języków Obcych (Beijing Foreign Studies University; BFSU/PUJO) - w 2010 r. ${ }^{16}$ Trzecia odsłona SPTK, zorganizowana w 2012 r. w Seulu przez Koreański Uniwersytet Języków Obcych (Hankuk University of Foreign Studies; HUFS), oznaczała powrót w mury uczelni, dzięki której rozpoczą się proces integracji wschodnioazjatyckich polonistyk. Ich czwarta konferencja odbyła się w 2014 r. - po raz kolejny gospodarzem był tokijski TUFS. Piąte spotkanie odbyło się w 2016 r. w Kantonie (chiń. Guanghzou), a jego organizatorem był Kantoński Uniwersytet Studiów Międzynarodowych (Guangdong University of Foreign Studies; GDUFS/KUSM). Gospodarzem szóstej konferencji był ponownie seulski HUFS, w $2018 \mathrm{r}$.

Każde spotkanie kończy tzw. okragły stół z udziałem przedstawicieli polonistyk krajów założycielskich, którzy dyskutuja o kontynuowaniu polonistycznej współpracy regionalnej w ramach SPTK. Yongdeog Kim wymienia najważniejsze tematy rozmowy:

15 A także z Polski. Warto wymienić zwłaszcza osoby, które uczestniczyły zarówno w konferencji w 2007 r., jak i ostatnim, jak na razie, SPTK: Władysław T. Miodunka, Renata Przybylska, Tomasz Lisowski i Jagna Malejka.

16 Dzięki obecności polonistów z Ułan Bator doszło po raz pierwszy do „spotkania polonistyk czterech krajów". 
1) zasady udziału w konferencji poszczególnych polonistyk azjatyckich; 2) zasady udziału naukowców $z$ Polski; 3) miejsca i terminy kolejnych spotkań; 4) SPTK a ewentualni nowi członkowie stowarzyszenia $z$ kilku nowych polonistyk w Chinach kontynentalnych oraz z polonistyk na Tajwanie, w Korei Północnej i z innych krajów ościennych, np. Wietnamu; 5) zasady dofinansowywania SPTK przez polskie instytucje rządowe oraz inne możliwości finansowania konferencji; 6) kontynuacja pozakonferencyjnych form działalności SPTK, np. wykłady gościnne, wizyty studyjne, warsztaty dydaktyczne, wspólne zajęcia dla studentów z Chin, Japonii i Korei, certyfikacja [Y. Kim 2018, 4].

Spotkanie $z$ okazji 20-lecia polonistyki na HUFS doczekało się w 2007 r. tomu pod redakcja Byunga Kwona Cheonga [2007]. Także po każdej konferencji SPTK ukazywała się publikacja zbierająca teksty wystapień. Jak dotąd ukazały się tomy pod redakcją: Tokimasy Sekiguchiego [2010], Ganga Zhao [2012], Estery Czoj (Sung Eun Choi) [2013], Kojiego Mority [2015], Yinhui Mao [2017] i Yongdeoga Kima [2018].

Zamieszczone w nich artykuły można zakwalifikować do następujących kategorii, ${ }^{17}$ np.:

- studia polonistyczne w Azji Wschodniej (funkcjonowanie poszczególnych ośrodków; dzieje nauczania JPJO w regionie itp.) - prace m.in.: B.K. Cheonga [2010], E. Czoj [2018], Y. Kima [2017], Yinan Li [2017], Yinhui Mao [2015], W.T. Miodunki [2018], K. Mority [2013], T. Sekiguchiego [2007, 2013], G. Zhao [2010, 2013];

- dydaktyka JPJO w Azji Wschodniej (także - specyfika nauczania studentów pochodzacych $z$ tego regionu) - prace m.in.: E. Czoj [2017], Tamary Czerkies [2018], Agnieszki Jasińskiej [2015], Piotra Kajaka [2017], Y. Li [2018], Jagny Malejki [2007, 2010], Rui Mao [2018], Barbary Morcinek [2007, 2012], Andrzeja Ruszera [2015];

- wzajemne kontakty kulturowe i przekłady literatury polskiej na języki makroregionu - prace m.in.: B.K. Cheonga [2018], E. Czoj [2010], Anny Ikedy [2013], Y. Kima [2013], Jiwone Lee [2013], Thuata Nguyena Chi [2018], J. Malejki [2015], T. Sekiguchiego [2018].

W innym miejscu pisałem [Kajak 2021], odwołując się do ustaleń i opinii T. Sekiguchiego, A. Ikedy oraz W.T. Miodunki, że specjaliści z Azji Północno-Wschodniej powołali środowisko polonistyczne, które zapracowało sobie na status bardzo istotnej części wspólnoty dyskursywnej glottodydaktyków polonistycznych. ${ }^{18}$ Inicjatywę lokalna byli w stanie przekształcić w projekt interesujący także polonistów $z$ innych krajów. Po raz kolejny warto przytoczyć słowa W.T. Miodunki, według którego to wspólne działanie zapewniło im odpowiednia widoczność i prestiż na tle polonistyki światowej - „przedstawiciele każdej z trzech polonistyk Dalekiego Wschodu $z$ osobna nie byliby w stanie tego osiagnąc w tym czasie"

17 Listę kategorii oparłem na propozycji Y. Kima [2018, 3].

18 Por. Zarzycka 2016 i 2019. 
[Miodunka 2018, 34]. Jeszcze raz odwołam się do opinii A. Ikedy, której zdaniem współpraca i integracja polonistyk $z$ regionu sprawiła,

że mimo dużego oddalenia od prężnie działających szkół języka polskiego jako obcego w Polsce, lektorzy nie czują się osamotnieni i pozostawieni samym sobie. Międzynarodowe konferencje akademickie SPTK stają się forami wymiany myśli, motywują do dalszych badań oraz poszerzaja perspektywy oglądu dydaktyki polonistycznej [Ikeda 2013, 34-35].

Proces integracji, nad którym czuwali poloniści z Pekinu, Seulu i Tokio, pozwolił na „rozprawienie się" $z$ typowym dla polonistów działajacych poza granicami Polski poczuciem bycia „mniejszościa” w świecie akademickim [Sekiguchi 2013, 21]. Integracja („najpierw z polonistami $z$ krajów sąsiednich, potem $z$ polonistami $z$ danej części świata, wreszcie $z$ polonistami $z$ całego świata, włączając do tego grona także wszystkich polonistów polskich" [Miodunka 2016, 347; Morcinek 2010]) pracowników naukowych uczelni, polonistów początkujących i studentów rozpoczynających „polska przygodę” wzmocniła ich pozycję nie tylko w świecie polonistyki międzynarodowej [Miodunka 2018, 34], ale także w lokalnym środowisku akademickim. Niewątpliwie zyskał na tym prestiż polszczyzny, a także jej moc (siła przyciagania zwłaszcza nowych użytkowników [Miodunka 1990, 2011]) na całym świecie, nie tylko w tym makroregionie, który $z$ roku na rok zyskuje na znaczeniu.

\section{Bibliografia}

[W zapisie bibliograficznym poszczególnych pozycji, zastępuję człon Spotkania polonistyk trzech krajów - Chiny, Korea, Japonia skrótowcem SPTK.]

Baza organizacji oraz instytucji polskich i polonijnych za granica Głównego Urzędu Statystycznego, styczeń 2019 (https://stat.gov.pl/obszary-tematyczne/ludnosc/polonia-i-polacy-w-swiecie/ baza-organizacji-i-instytucjipolskich-i-polonijnych-za-granica,2,3.html [dostęp: 14.01.2021]).

M. Burdelski, 2010, 60 lat stosunków Polski z ChRL - rys historyczny [w:] J. Włodarski, K. Zeidler, M. Burdelski (red.), Chiny w oczach Polaków. Państwospołeczeństwo - kultura. Ksiega jubileuszowa z okazji 60-lecia nawiazania stosunków dyplomatycznych między Polska a Chinska Republika Ludowa, Gdańsk, s. 129-162.

B.K. Cheong (red.), 2007, Studia Polonistyczne w Azji, Seul.

B.K. Cheong, 2010, Ślady polskich wykładowców na koreańskim uniwersytecie HUFS [w:] T. Sekiguchi (red.), SPTK - Rocznik 2009, Tokio, s. 59-68.

B.K. Cheong, 2018, „Lalka” Bolesława Prusa po koreańsku [w:] Y. Kim (red.), SPTK - Rocznik 2018/2019, Seul, s. 67-71.

S.E. Choi (E. Czoj), 2010, Korea w polskich utworach literackich - od pierwszej wzmianki do współczesności [w:] T. Sekiguchi (red.), SPTK - Rocznik 2009, Tokio, s. 69-94. 
S.E. Choi (E. Czoj) (red.), 2013, SPTK-Rocznik 2012/2013, Seul.

S.E. Choi (E. Czoj), 2017, Studium porównawcze nad metaforami $w$ polskich $i$ koreańskich przysłowiach $w$ perspektywie nauczania języka polskiego jako obcego [w:] Y. Mao (red.), SPTK-Rocznik 2016/2017, Kanton, s. 361-384.

S.E. Choi (E. Czoj), 2018, Ustawa w sprawie wspierania edukacji rzadkich języków obcych - szansa na wypromowanie języka polskiego w Republice Korei [w:] Y. Kim (red.), SPTK - Rocznik 2018/2019, Seul, s. 109-119.

T. Chomicki, 2009, Metrem do Azji, „Znak” nr 646, s. 39-53.

T. Czerkies, 2018, Od negocjacji znaczeń do mediacji - literatura $w$ nauczaniu języka polskiego jako obcego [w:] Y. Kim (red.), SPTK-Rocznik 2018/2019, Seul, s. 173-187.

A. Dąbrowska, 2008, Róbmy swoje! Blaski i cienie promocji języka polskiego na świecie [w:] J. Warchala, D. Krzyżyk (red.), Polska polityka językowa w Unii Europejskiej, Katowice, s. 179-192.

A. Dąbrowska, W.T. Miodunka, A. Pawłowski, 2012, Wyzwania polskiej polityki językowej za granica: kontekst, cele, środki i grupy odbiorcze, Warszawa.

S. Dubisz (red.), 1997, Język polski poza granicami raju, Opole.

S. Dubisz, 2001, Polska, Polonia, polonistyka a Europa, "Poradnik Językowy” z. 1, s. 3-11.

S. Dubisz, 2007, Język polski poza granicami etnicznymi, „Kwartalnik Polonicum" nr 4, s. 2-10.

S. Dubisz, 2013, Sytuacja języka polskiego w świecie, „Poradnik Językowy” z. 8, s. $5-12$.

S. Dubisz, 2015, „Dwadzieścia lat później” - język polski poza granicami krajuhistoria badań i ich perspektywy, „Poradnik Językowy” z. 8, s. 7-17.

S. Dubisz, 2020, Polityka językowa, „Poradnik Językowy” z. 9, s. 118-120.

Dyplomacja publiczna 2012, 2012, raport Ministerstwa Spraw Zagranicznych RP, https://www.msz.gov.pl/resource/019d6590-c271-4462-9f3d-09cd5410795b:JCR [dostęp: 13.07.2020 r.).

S. Gajda, 1999, Program polskiej polityki językowej, „Poradnik Językowy” z. 5-6, s. $1-10$.

S. Gajda, 1999a, Program polskiej polityki językowej (rozważania wstępne) [w:] J. Mazur (red.), Polska polityka językowa na przełomie tysiacleci, Lublin, s. 37-46.

S. Gajda, A. Markowski, J. Porayski-Pomsta (red.), 2005, Polska polityka komunikacyjnojęzykowa wobec wyzwań XXI wieku, Warszawa.

T. Garbacik-Jeziorska, 2011, Opracowanie dotyczace systemów promocji języka za granica stosowanych przez wybrane państwa, Warszawa.

P. Gębal, W.T. Miodunka, 2020, Dydaktyka i metodyka nauczania języka polskiego jako obcego i drugiego, Warszawa.

A. Ikeda, 2013, Dwujęzyczność - wiedza potoczna, a ujęcie psycholingwistyczne (na podstawie doświadczeń polsko-japońskich) [w:] S.E. Choi (red.), SPTKRocznik 2012/2013, Seul, s. 81-96.

A. Ikeda, 2013, W obliczu zmian - nowe projekty i przedsięwzięcia na polonistyce tokijskiej [w:] J. Mazur, A. Małyska, K. Sobstyl (red.), Glottodydaktyka polonistyczna w obliczu dynamiki zmian językowo-kulturowych i potrzeb społecznych, t. 1, Lublin, s. 107-116.

M. Jacoby, 2013, Działalność Instytutu Adama Mickiewicza w Azji, „Azja-Pacyfik" t. XVI, s. 90-110. 
A. Jasińska, 2015, Dialog międzykulturowy jako próba wzajemnego oswajania kultur. Rola programów kulturalnych w nauczaniu języka polskiego jako obcego - z doświadczeń warszawskiej nauczycielki [w:] K. Morita (red.), SPTK - Rocznik 2014/2015, Tokio, s. 265-272.

D. Jurkiewicz-Eckert, 2016, Projekt Azja i strategia brandingu Polski przez kulture w Azji Wschodniej i Południowej w latach 2010-2015, „Studia Europejskie" nr 3, s. 147-168.

P. Kajak, 2017, Budowanie bazy fanów języka polskiego i kultury polskiej w Azji - przypadek indyjski i południowokoreański [w:] Y. Mao (red.), SPTK-Rocznik 2016/2017, Kanton, s. 233-242.

P. Kajak, 2021, Współdziałanie dyplomacji publicznej z glottodydaktyka polonistyczna na przykładzie Chin [w:] A. Jasińska, P. Kajak, T. Wegner (red.), Język polski $w$ Chinach. $Z$ doświadczeń nauczania polszczyzny $w$ Azji Wschodniej, Warszawa (w przygotowaniu).

Y. Kim, 2013, Historia Korei w historii Polski [w:] S.E. Choi (red.), SPTK-Rocznik 2012/2013, Seul, s. 241-256.

Y. Kim, 2017, Historia Polski w oczach koreańskich studentów Departamentu Studiów Polskich HUFS. Stan i perspektywy [w:] Y. Mao (red.), SPTK-Rocznik 2016/2017, Kanton, s. 409-426.

Y. Kim, 2018, Przedmowa [w:] Y. Kim (red.), SPTK-Rocznik 2018/2019, Seul, s. $1-5$.

Y. Kim (red.), 2018, SPTK - Rocznik 2018/2019, Seul.

J. Lee, 2013, Janusz Korczak w ksiażkach dla dzieci w Korei - „Pochód aniołów” $i$ „Pamiętnik Blumki” [w:] S.E. Choi (red.), SPTK-Rocznik 2012/2013, Seul, s. $181-192$.

Y. Li, 2017, Dydaktyka polonistyczna wobec inicjatywy Jeden pas, jeden szlak: program i metody [w:] Y. Mao (red.), SPTK - Rocznik 2016/2017, Kanton, s. 387-398.

Y. Li, 2018, Chinsko-polskie tłumaczenie ustne i pisemne: program dydaktyczny i jego wdrażanie $w$ praktyce tłumaczeniowej [w:] Y. Kim (red.), SPTK-Rocznik 2018/2019, Seul, s. 347-355.

Y. Li, 2018, Wymiana literacka $w$ dyplomacji publicznej - nowe wyzwania dla instytucji polonistycznych w nowej epoce [w:] R. Cudak, K. Pospiszil, A. Tambor, A. Rudzińska (red.), Literatura (i kultura) polska w świecie, Katowice, s. 320-332.

W. Lubaś, 1999, Co jest teraz ważne w polskiej polityce językowej [w:] J. Mazur (red.), Polska polityka językowa na przełomie tysiacleci, Lublin, s. 25-36.

W. Lubaś, 2009, Polityka językowa. Komparacja współczesnych języków słowiańskich, Opole.

W. Lubaś, 2012, O polskiej polityce językowej, „Poradnik Językowy” z. 6, s. 11-33.

J. Malejka, 2007, Jak uczyć studentów chińskich wymowy polskiej [w:] B.K. Cheong (red.), Studia polonistyczne w Azji, Seul, s. 159-167.

J. Malejka, 2010, Na głęboka wode - o zaletach (i wadach) komunikowania sie $z$ Chińczykami wyłacznie po polsku [w:] T. Sekiguchi (red.), SPTK-Rocznik 2009, Tokio, s. 167-178.

J. Malejka, 2015, Karateka, dżudoka i... „sumoka”? O kilku zapożyczeniach z języka japońskiego w polszczyźnie, ich adaptacji i opisie leksykograficznym [w:] K. Morita (red.), SPTK - Rocznik 2014/2015, Tokio, s. 331-341. 
R. Mao, 2018, Postęp w mówieniu po polsku początkujących Chinczyków (na przykładzie studentów Szanghajskiego Uniwersytetu Studiów Międzynarodowych) [w:] Y. Kim (red.), SPTK-Rocznik 2018/2019, Seul, s. 411-418.

Y. Mao, 2015, O promocji języka polskiego i kultury polskiej w Chinach Południowych w ostatnich latach [w:] K. Morita (red.), SPTK - Rocznik 2014/2015, Tokio, s. 147-159.

Y. Mao (red.), 2017, SPTK-Rocznik 2016/2017, Kanton.

J. Mazur (red.), 1998, Promocja języka i kultury polskiej w świecie, Lublin.

J. Mazur (red.), 1999, Polska polityka językowa na przełomie tysiącleci, Lublin 1999.

J. Mazur, 2000, Stan i perspektywy polonistyki na świecie [w:] J. Mazur (red.), Polonistyka w świecie. Nauczanie języka i kultury polskiej studentów zaawansowanych, Lublin, s. 15-25.

J. Mazur, M. Rzeszutko-Iwan (red.), 2007, Język polski jako narzędzie komunikacji we współczesnym świecie, Lublin.

W.T. Miodunka, 1990, Moc języka i jej znaczenie w kontaktach językowych i kulturowych [w:] W.T. Miodunka (red.), Język polski w świecie, Warszawa 1990, s. 39-49.

W.T. Miodunka, 2000, Polonistyka czy studia polskie dla cudzoziemców? O przyszłości polonistyki polemicznie [w:] J. Mazur (red.), Polonistyka w świecie. Nauczanie języka $i$ kultury polskiej studentów zaawansowanych, Lublin, s. 27-37.

W.T. Miodunka, 2007, Polonistyka koreańska $w$ historii nauczania języka polskiego w świecie [w:] B.K. Cheong (red.), Studia polonistyczne w Azji, Seul, s. 25-32.

W.T. Miodunka, 2010, Glottodydaktyka polonistyczna $w$ dobie globalizacji i informatyzacji [w:] R. Nycz, W.T. Miodunka, T. Kunz (red.), Polonistyka bez granic, t. 2, Kraków, s. 41-54.

W.T. Miodunka, 2011, Między etniczno-genealogicznym a kulturowym rozumieniem narodu. O potrzebie historycznojęzykowych badań polszczyzny jako języka obcego $i$ drugiego, „LingVaria VI” nr 1, s. 179-204.

W.T. Miodunka, 2016, Glottodydaktyka polonistyczna. Pochodzenie - stan obecny - perspektywy, Kraków.

W.T. Miodunka, 2018, Spotkania Polonistyk Trzech Krajów jako model polonistycznej wspótpracy regionalnej. Osiagnięcia i perspektywy polonistyk dalekiego Wschodu [w:] Y. Kim (red.), SPTK-Rocznik 2018/2019, Seul, s. 29-38.

W.T Miodunka, 2020, Rozpowszechnianie, zachowywanie i nauczanie języka polskiego w świecie w latach 1918-2018. Część II: Polszczyzna i Polonia $w$ świecie $w$ latach 1944-2018, „Poradnik Językowy” z. 2, s. 7-28.

W.T Miodunka, J. Tambor i in. (red.), 2018, Nauczanie i promocja jezyka polskiego w świecie: diagnoza, stan, perspektywy, Katowice.

B. Morcinek, 2007, Gesty po polsku i po japońsku - komunikacja niewerbalna w procesie nauczania języka polskiego jako obcego [w:] B.K. Cheong (red.), Studia Polonistyczne w Azji, Seul, s. 137-157.

B. Morcinek, 2010, Spotkania polonistyk trzech krajów: Chiny - Korea - Japonia, „Postscriptum Polonistyczne” nr 2 (6), s. 261-268.

B. Morcinek, 2012, Film popularny w nauczaniu kultury polskiej i języka polskiego jako obcego [w:] G. Zhao (red.), SPTK - Rocznik 2010/2011, Pekin, s. 65-70. 
K. Morita, 2013, Nauczanie języka polskiego $w$ Kioto $i$ Kobe - sprawozdanie z lat 2010-2013 [w:] S.E. Choi (red.), SPTK-Rocznik 2012/2013, Seul, s. 201-203.

K. Morita, 2015, Nowe horyzonty $w$ popularyzacji języka $i$ kultury polskiej na TUFS-ie [w:] K. Morita (red.), SPTK-Rocznik 2014/2015, Tokio, s. 33-39.

K. Morita (red.), 2015, SPTK - Rocznik 2014/2015, Tokio.

T. Nguyen Chi, 2018, Recepcja „Lalki” Bolesława Prusa w Wietnamie na tle polskich powieści dziewiętnastowiecznych [w:] Y. Kim (red.), SPTK - Rocznik 2018/2019, Seul, s. 53-66.

A. Pawłowski, 2008, Język polski w Unii-szanse i zagrożenia [w:] J. Warchala, D. Krzyżyk (red.), Polska polityka językowa w Unii Europejskiej, Katowice, s. $113-147$.

A. Pawłowski, 2015, Promocja języka polskiego - między lingwistyka a marketingiem, „Poradnik Językowy” z. 8, s. 143-155.

W. Pisarek, 1999, Istota i sens polskiej polityki językowej [w:] J. Mazur (red.), Polska polityka językowa na przełomie tysiacleci, Lublin, s. 13-23.

D. Quah, 2011, The Global Economy's Shifting Centre of Gravity, „Global Policy” nr 2, s. 3-9.

A. Ruszer, 2015, Prace licencjackie $w$ Pekinie-język polski narzędziem czy przedmiotem refleksji? [w:] K. Morita (red.), SPTK - Rocznik 2014/2015, Tokio, s. $183-194$.

T. Sekiguchi, 1997, Polonistyka w Japonii [w:] B. Janowska, J. Porayski-Pomsta (red.), Jezzyk polski w kraju i za granica, t. II, Warszawa, s. 209-217.

T. Sekiguchi, 2007, 15 lat Seminarium Kultury Polskiej na TUFS [w:] B.K. Cheong (red.), Studia polonistyczne w Azji, Seul, s. 57-72.

T. Sekiguchi, 2010, Przedmowa [w:] T. Sekiguchi (red.), SPTK - Rocznik 2009, Tokio, s. 5-8.

T. Sekiguchi (red.), 2010, SPTK-Rocznik 2009, Tokio.

T. Sekiguchi, 2013, Bristol, Kongresy, SPTK... Przyczynek do historii organizowania międzynarodowych wspólnot polonistów [w:] S.E. Choi (red.), SPTKRocznik 2012/2013, Seul, s. 15-22.

T. Sekiguchi, 2013, Nowe horyzonty glottodydaktyki polonistycznej-Tokio, Seul, Pekin [w:] J. Mazur, A. Małyska, K. Sobstyl (red.), Glottodydaktyka polonistyczna w obliczu dynamiki zmian językowo-kulturowych i potrzeb społecznych, t. I, Lublin, s. 99-106.

T. Sekiguchi, 2014, Światowy Kongres Polonistów [w:] S. Gajda, I. Jokiel (red.), Polonistyka wobec wyzwań współczesności, t. 2, Opole, s. 774-775.

T. Sekiguchi, 2018, Diabły tkwia $w$ przypisach $-z$ warsztatu japońskiego tłumacza „Lalki” Bolesława Prusa [w:] Y. Kim (red.), SPTK - Rocznik 2018/2019, Seul, s. 39-46.

E. Sękowska, 2010, Język emigracji polskiej w świecie. Bilans i perspektywy badawcze, Kraków.

J. Skoczek, 2021, Nauczanie języka polskiego jako zadanie i narzędzie dyplomacji publicznej [w:] A. Jasińska, P. Kajak, T. Wegner (red.), Język polski w Chinach. $Z$ doświadczeń nauczania polszczyzny $w$ Azji Wschodniej, Warszawa (w przygotowaniu).

Studenci zagraniczni $w$ Polsce 2016, raport Study in Poland, Fundacja Edukacyjna Perspektywy, https:// perspektywy.pl/portal/index.php?option=com_ content\&view=article\&id=2899:w-polsce-studiuje-57-119-studentow-zagran icznych-ze-157-krajow\&catid=22\&Itemid=119 [dostęp: 11.01.2021]. 
Studenci zagraniczni $w$ Polsce 2017, raport Study in Poland, Fundacja Edukacyjna Perspektywy, http://studyinpoland.pl/konsorcjum/index.php?option=com_content\&view $=$ article\&id=14515:raport-studenci-zagraniczi -w-polsce-2017\&catid=258:145-newsletter-2017\&Itemid=100284 [dostęp: 11.01.2021].

Szkolnictwo wyższe i jego finanse w 2019 roku, raport Głównego Urzędu Statystycznego $z$ dn. 30.10.2020 r., https://stat.gov.pl/obszary-tematyczne/ edukacja/edukacja/szkolnictwo-wyzsze-i-jego-finanse-w-2019-roku,2,16. html [dostęp: 11.01.2021].

R. Szul, 2009, Język, naród, państwo. Język jako zjawisko polityczne, Warszawa.

K. Szumski, 2013, Polska polityka zagraniczna wobec Azji i Pacyfiku po 1989 roku, „Azja-Pacyfik” t. XVI, s. 9-37.

B. Walczak, A. Mielczarek, 2013, Glottodydaktyka polonistyczna wobec zmian w językowej sytuacji świata [w:] J. Mazur, A. Małyska, K. Sobstyl (red.), Glottodydaktyka polonistyczna w obliczu dynamiki zmian językowo-kulturowych i potrzeb społecznych, t. I, Lublin, s. 41-48.

J. Warchala, D. Krzyżyk (red.), 2008, Polska polityka językowa w Unii Europejskiej, Katowice.

J. Wardęga, 2017, Chinczycy w Polsce - niewidoczna mniejszość, „Studia Migracyjne - Przegląd Polonijny" z. 2 (164), s. 121-141.

K. Wrocławski, 2006, Polonicum w moich wspomnieniach (lata 1965-1978) [w:] E. Rohozińska, M. Skura, A. Piasecka (red.), Na chwałe i pożytek nasz wzajemny. Złoty jubileusz Polonicum, Warszawa, s. 73-85.

K. Wysieńska (red.), 2012, Sprzedawać, gotować, budować? Plany i strategie Chińczyków $i$ Wietnamczyków w Polsce, Warszawa.

G. Zarzycka, 2016, O wspólnocie dyskursywnej glottodydaktyków polonistycznych [w:] I. Janowska, P.E. Gębal (red.), O lepsze jutro studiów polonistycznych w świecie. Glottodydaktyka polonistyczna dziś, Kraków, s. 15-34.

G. Zarzycka, 2019, Dyskursy polonistyczne w Seulu: O VI Międzynarodowej Konferencji Akademickiej z cyklu "Spotkania Polonistyk Trzech Krajów - Chiny, Korea, Japonia”, „Acta Universitatis Lodziensis - Kształcenie Polonistyczne Cudzoziemców" nr 26, s. 501-514.

Y. Zhang, 2021, Nauczanie języka polskiego $w$ Chinach $w$ nowej rzeczywistości społeczno-politycznej [w:] A. Jasińska, P. Kajak, T. Wegner (red.), Język polski $w$ Chinach. $Z$ doświadczeń nauczania polszczyzny w Azji Wschodniej, Warszawa (w przygotowaniu).

G. Zhao, 2010, Dydaktyka polonistyczna na BFSU - realia i wyzwania [w:] T. Sekiguchi (red.), SPTK - Rocznik 2009, Tokio, s. 129-134.

G. Zhao (red.), 2012, SPTK-Rocznik 2010/2011, Pekin.

G. Zhao, 2013, O różnicy między chińska a polska polityka językowa [w:] S.E. Choi (red.), SPTK - Rocznik 2012/2013, Seul, s. 225-229. 


\section{Instruments for promoting the Polish language worldwide: Tripartite Polish Studies Meetings: China, Korea, Japan (SPTK)}

\section{Summary}

One of the most important initiatives serving the purpose of popularising the Polish language worldwide is the Meetings of Polish Studies in Three Countries: China, Korea, Japan (SPTK). The actions taken by specialists in Polish studies coming from East Asian countries position the teaching of Polish as a foreign language in a new sociopolitical context. Polish studies function at prestigious higher education institutions of the region, the significance of which increases as a result of the changes occurring in the contemporary international relations. Polish glottodidactics becomes one of the "tools" in the public diplomacy efforts made by the Polish government at various levels using various means. The cooperation and integration of Asian specialists in Polish studies raises the global prestige of the Polish language and develops polonophony.

Keywords: SPTK (Meetings of Polish Studies in Three Countries) - China - Korea - Japan - Polish as a foreign language - public diplomacy - language policy Polish studies abroad.

Trans. Monika Czarnecka 